\title{
PENGEMBANGAN ENTERPRENEUR MAHASISWA DALAM USAHA BATAKO DI WORKSHOP PTB UNS
}

\author{
Ida Nugroho Saputro ${ }^{1}$ \\ Anis Rahmawati ${ }^{1}$ \\ Waluyo $^{1}$ \\ Aryanti Nurhidayati ${ }^{1}$ \\ ${ }^{1}$ Pendidikan Teknik Bangunan \\ Fakultas Keguruan dan Ilmu Pendidikan \\ Universitas Sebelas Maret Surakarta \\ email: nugroho.saputro@yahoo.co.id
}

\begin{abstract}
ABSTRAK
Bata beton (batako) merupakan salah satu jenis beton non struktural yang dapat dimanfaatkan untuk keperluan jalan, pelataran parkir, trotoar, taman, dan keperluan lainnya. Bata beton terbuat dari campuran semen portland tipe I dan air serta agregat sebagai bahan pengisi. Penggunaan batako dalam bangunan dibandingkan dengan bata merah lebih ramah lingkungan. Sedangkan penggunaan batako memang sangat bertumbuh pesat saat ini terutama di kota Solo karena pertumbuhan perumahan dan perkantoran yang semakin pesat.

Melihat perkembangan kebutuhan akan batako yang pesat maka workshop Pendidikan Teknik Bangunan (PTB) mengembangkan menjadi program kewirausahaan batako. Program ini diwujudkan melalui kewirausahaan kampus yang dikelola oleh mahasiswa untuk belajar berwirausaha. Program pengembangan kampus meliputi pelatihan enterpreneur bagi mahasiswa, membentuk unit produksi batako dan inkubasi usaha batako yang pada akhirnya menghasilkan wirausawan yang baru. Workshop PTB masih tersedia lahan yang cukup luas untuk mengembangkan enterpreneur kampus. Dari hasil kegiatan kewirausahaan mahasiswa dapat mengembangkan unit usaha batako sehingga bisa menjadi sebagai sumber tambahan pendapatan.

Hasil kegiatan kewirausahaan kampus telah terbentuk unit usaha batako dan kantor pengelolaan yang berada di kampus Pabelan UNS. Pada kegiatan ini melibatkan 10 mahasiswa dari berbagai program studi yang paling banyak dari program studi PTB. Batako yang dihasilkan 2 jenis antara lain batako pejal dan
\end{abstract}


batako berlubang. Produk yang dihasilkan berjumlah 600 buah dengan ukuran $10 \mathrm{~cm} \times 15 \mathrm{~cm} \times 30 \mathrm{~cm}$ dan $10 \mathrm{~cm} \times 20 \mathrm{~cm} \times 40 \mathrm{~cm}$. Ukuran ini yang biasa dipakai untuk membuat dinding pada rumah maupun bangunan sehingga sesuai dengan kebutuhan dari masyarakat.

Kata kunci : batako, kewirausahaan, kampus, workshop

\begin{abstract}
Concrete brick is a kind of non structural brick which can be used for street, parking lot, sidewalk, park and another necessity. Concrete brick is made of the mixture of portland cement type one, water and aggregate as the filler materials. The ussage of concrete brick is more eco friendly compared with brick, moreover the ussage of concrete brick grows rapidly, especially in Solo lately because of the rapid growth of housing estate and bisnis area.

Observing the expansion of the concrete brick necessity so Pendidikan Teknik Bangunan (PTB) workshop develop it to concrete brick entrepreneurship program. This program was aimed through college entrepreneurship which is managed by the unversity students to study about entrepreneurhip. The college developing program are entrepreneurship training for the students, form a concrete brick production unit, incubation of the concrete brick bisnis and creating a new entrepreneur as the result. PTB workshop has and enough place for the development of the college entrepreneur. From the result of entrepreneurship activity the students can develop cncrete brick bisnis unit so it can be used as a additional income.

The result of college entrepreneurship activity has made a concrete brick bisnis unit and management office in Pabelan Campus UNS. This activity is involving ten university students from various major, mostly from PTB major. There are two kinds of concrete brick that has been made; Rejal concrete brick and hollow concrete brick. Six hundred concrete brick has been made with the size $10 \mathrm{~cm} \times 15$ $\mathrm{cm} \times 30 \mathrm{~cm}$ and $10 \mathrm{~cm} \times 20 \mathrm{~cm} \times 40 \mathrm{~cm}$. This size is usually used as a wall or building to adjust the needs of the society.
\end{abstract}

Keywords : concrete brick, entrepreneurship, college, workshop. 


\section{PENDAHULUAN}

Workshop pendidikan teknik bangunan bagian dari program studi Pendidikan Teknik Bangunan (PTB) Fakultas Keguruan dan Ilmu Pendidikan UNS. Workshop ini berlokasi di Kampus V Jl ahmad Yani Surakarta masuk wilayah Solo bagian barat. Program studi Pendidian Teknik Bangunan mempunyai 6 workshop dan 2 laboratorium untuk menunjang proses pembelajaran dikampus dan penelitian yang dilakukan dosen maupun mahasiswa. Workshop ini menghasilkan barang/karya dari hasil proses pembelajaran antara dosen dan mahasiswa. Pada workshop batu beton menghasilkan hasil-hasil praktek yang terbuat dari bahan campuran beton antara lain batako, paving blok, plat beton dll.

Bata beton (batako/paving blok ) merupakan salah satu jenis beton non struktural yang dapat dimanfaatkan untuk keperluan jalan, pelataran parkir, trotoar, taman, dan keperluan lainnya. Bata beton terbuat dari campuran semen portland tipe I dan air serta agregat sebagai bahan pengisi. Penggunaan batako dalam bangunan dibandingkan dengan bata merah lebih ramah lingkungan. Proses pembuatan batako lebih mudah dibandingkan dengan bata merah. Proses pembuatan batako/paving blok dicampur campuran antara pasir, air dan semen setelah kering langsung digunakan. Proses ini berbeda dengan pembuatan bata merah yang bahan dasarnya berasal dari tanah dan proses produksi dengan cara dibakar menggunakan kayu. Bahan bangunan batako lebiih ramah lingkungan dari pada bata merah

Melihat perkembangan perumahan yang begitu pesat di Solo dan sekitarnya, banyak dibangun perumahan-perumahan baru untuk memenuhi kebutuhan bahan bangunan yang begitu besar. Bahan bangunan berupa perkerasan jalan dengan menggunakan paving block yang ramah terhadap ecogreen. Semakin banyak menggunakan paving block semakin bertambah resapan air kedalam tanah 
yang. Pada dasarnya mengurangi debit air yang ada dipermukaan tanah sehingga banjir dapat dihindari. Bahan bangunan batako/pavingblok banyak digunakan membangun perumahan terbukti dengan adanya pembangunan rumah maupun renovasi. Hal ini terkait dengan program pemerintah dalam mengatasi kurangnya hunian perumahan.

Hasil observasi tim pelaksana melihat potensi untuk bisa mengembangkan workshop PTB khususnya workshop batu beton dikembangkan menjadi unit usaha pembuatan batako. Dilihat dari pemasaran sangat potensial hampir semua bangunan menggunakan bahan bangunan batako. Program pengembangan kampus direncanakan meliputi pelatihan enterpreneur bagi mahasiswa, membentuk unit produksi batako dan inkubasi usaha batako yang pada akhirnya menghasilkan wirausawan yang baru..

Menurut data BPPT (2010), Indonesia selalu mengalami penambahan angkatan kerja dari tahun

ke tahun. Misalnya selama periode 2009-2010 lalu, telah terjadi penambahan angkatan kerja sebanyak 2,26 juta orang, tepatnya meningkat dari 111,48 juta orang menjadi 113,74 juta orang. Pertambahan pasokan tenaga kerja sebanyak ini tidak seluruhnya terserap oleh pasar kerja, sehingga membuat tingkat pengangguran mencapai $8,14 \%$ atau 9,26 juta orang. Dari 9,26 juta orang pengangguran ini, diploma dan sarjana yang menganggur masing-masing sekitar 1.260 .000 orang dan 1.424 .000 orang. Sementara itu, pelaku usaha kecil dan menengah (UKM) sebagai entrepreneur yang berasal dari angkatan kerja tersebut diatas sangatlah sedikit. Dari data yang ada, jumlah enterpreneur di Indonesia tergolong masih sangat kecil, yaitu baru sekitar $0,18 \%$ dari jumlah penduduk. Sedangkan di Amerika telah mencapai $11 \%$, Singapore $7 \%$, Korea dan Jepang di atas 5\%, negara-negara Eropa rata-rata di atas $4 \%$, dan India hampir 2\% (BPPT, 2010). 
Merujuk pada kondisi di atas, bidang ilmu yang berkaitan dengan maka upaya mempercepat tumbuhnya teknologi dan industri. Karena itu, usaha-usaha baru menjadi sangat pendidikan kewirausahaan teknologi penting, terutama dalam merespon (technopreneurship) bisa dijadikan semakin meningkatnya pasokan tenaga kerja dari tahun ke tahun. Salah satu sebagai sebuah proses pembelajaran beratmosfir bisnis. Pendidikan upaya mempercepat tumbuhnya usahatechnopreneurship ke depan sangat usaha baru adalah membuat terobosanmemungkinkan untuk dikembangkan terobosan melalui perubahan pola pandang (mindset) lulusan perguruan tinggi dari status sebagai pencari kerja menjadi pencipta kerja. Untuk mewujudkan upaya ini, sebenarnya perguruan tinggi telah memberikan pembekalan melalui mata kuliah kewirausahaan. Namun, dalam pelaksanaannya masih lebih besar pada aspek teori. Meskipun begitu, hal ini sudah bisa menjadi modal dasar yang sangat baik. Selanjutnya, materi kewirausahaan tersebut tinggal ditambahkan berinovasi melalui penerapan teknologi.

Pendidikan kewirausahaan berbasis teknologi, atau dikenal dengan istilah technopreneurship, merupakan upaya untuk mensinergikan antara teori dan praktik dari berbagai kompetensi pada perguruan tinggi di Indonesia. Akan tetapi dalam pengembangannya, perguruan tinggi masih dihadapan berbagai permasalahan baik belum adanya kebijakan maupun kesiapan dari perguruan tinggi (tenaga pengajar dan Infrastruktur pendidikan). Hal yang terjadi diatas juga dialami oleh lulusan perguruan tinggi dari UNS umumnya dan lulusan program studi Pendidikan Teknik Bangunan khususnya, yaitu masih rendahnya lulusan yang terjun ke dunia wirausaha.

Berdasarkan pemikiran dan fakta lapangan sebagaimana diungkap di atas, maka kami ingin ikut berpartisipasi melalui program pengabdian masyarakat kewirausahaan kampus untuk menciptakan technopreneur-technopreneur baru di 
bidang property khususnya usaha dilaksanakan dalam beberapa tahapan pembuatan bahan bangunan batako yaitu:

dan paving. Sasaran dari kegiatan ini

\section{A. Proses Rekruitmen}

adalah mahasiswa Program studi

Pendidikan Teknik Bangunan khususnya dan mahasiswa UNS umumnya. Melalui pelatihan ini diharapkan dapat menghasilkan wirausaha baru yang mampu membuka lapangan kerja untuk dirinya maupun orang lain.

\section{METODE PENELITIAN}

$$
\text { Kegiatan }
$$

enterpreneur

kampus ini dilaksanakan Kampus

Pabelan UNS JI Ahmad Yani 200 Surakarta. Kegiatan dari program kewirausahaan kampus untuk menciptakan technopreneurtechnopreneur baru di bidang property khususnya usaha pembuatan bahan bangunan batako. Sasaran dari kegiatan ini adalah mahasiswa Program studi Pendidikan Teknik Bangunan khususnya dan mahasiswa UNS umumnya. Melalui pelatihan ini diharapkan dapat menghasilkan wirausaha baru yang mampu membuka lapangan kerja untuk dirinya maupun orang lain. Kegiatan
Proses rekruitmen peserta training technopreneurship rencana akan dilakukan selama 2 kali dalam satu tahun periode pelaksanaan kewirausahaan kampus. Setiap kali pelaksanaan training akan melibatkan peserta sebanyak 10 orang. Kegiatan pengembangan kewirausahaan berbasis teknologi ini akan merekrut mahasiswa tahun terakhir kuliah, sehingga sebagai pembekalan nantinya kalau sudah lulus untuk terjun ke dunia kerja. Pelaksanaan training technopreneurship ini dirancang untuk 10 orang mahasiswa yang dipilih melalui proses seleksi di Prodi PTB untuk mendapatkan mahasiswa (peserta) yang memiliki motivasi tinggi untuk mengembangkan kewirausahaan yang berbasis teknologi melalui praktik bisnis secara nyata. Proses seleksi akan dilakukan dengan cara wawancara dengan calon peserta training technopreneurship. 


\section{B. Proses Pemagangan}

Untuk itu melalui pelatihan ini, peserta akan dibekali hal-hal sebagai berikut : peserta mulai diperkenalkan dan sekaligus dilatih untuk mengenal peluang usaha, bagaimana menemukannya, bagaimana memilihnya, dan bagaimana memulainya. Dari berbagai peluang yang ada, peserta diajak untuk berlatih menyusun perencanaan usaha sesuai dengan minatnya masing-masing yang dipandang memiliki prospek yang sangat baik untuk dijadikan pilihan usaha. Peserta diberi pengetahuan mengenai teknis pembuatan batako, pencampuran adukan batako, takaran perbandingan campuran, pencetakan batako, proses pengeringan dan penyimpanan batako. Peserta diminta melakukan kunjungan lapangan dan ikut melaksanakan praktik pembatan batako pada usaha pembuatan batako secara keseluruhan yang diikuti secara kolektif semua peserta pelatihan. Namun akan dibagi kedalam kelompok, agar transfer teknologi bisa dilakukan dengan efektif dan efisien. Selanjutnya peserta akan langsung praktik lapangan dalam pembuatan batako. Bentuk lain tentang model praktik bisnis selama pelatihan secara simulasi. Hal ini disesuaikan dengan kondisi dan situasi di mana tempat pelatihan diselenggarakan.

\section{Proses Inkubasi Technopreneur}

Peserta training/pelatihan adalah mahasiswa yang mempunyai minat dan motivasi yang kuat untuk mendalami bidang kewirausahaan. Jumlah peserta pelatihan setiap periode terdiri atas 10 peserta.

Pelatihan dilaksanakan selama 5 hari efektif@6 jam atau 30 jam (dimulai jam 08.00-15.00). Pelatihan akan dilaksanakan di Workshop PTB baik secara kelas maupun secara praktik lapangan. Kompetensi yang diharapkan bagi peserta pelatihan dengan menggunakan modul ini adalah sebagai berikut :

1. Memiliki jiwa dan sikap positif terhadap kewirausahaan sebagai pilihan karier 
2. Memahami konsep dasar kewirausahaan

3. Mengidentifikasi komponenkomponen manajemen usaha kecil yang terdiri dari aspek produksi, pemasaran, permodalan dan keuangan, serta sumberdaya manusia dan jaringan untuk keperluan praktik wirausaha

4. Mampu memilih bentuk-bentuk badan usaha yang sesuai dengan jenis usaha yang akan dikembangkan serta proses legalitasnya sesuai dengan ketentuan yang berlaku

5. Memiliki keterampilan menyusun perencanaan usaha sesuai dengan pilihan jenis usaha yang akan dikembangkan

6. Memiliki ketrampilan teknis pembuatan batako

Pelatihan ini menggunakan pendekatan 'andragogi', mengutamakan partisipasi dari peserta. Materi disajikan sebagai penguatan, sedangkan porsi yang lebih besar diberikan dalam bentuk diskusi, penugasan, simulasi dan/atau praktik.
Semua tugas atau praktik yang diminta oleh Instruktur (baik tugas individual maupun kelompok) harus dipenuhi sebagai bagian dari proses pencapaian kompetensi lulusan.

Strategi penyampaian materi dilakukan dengan :

1. Ceramah

2. Simulasi

3. Diskusi dan tanya jawab

4. Penugasan

5. Presentasi

6. Kunjungan lapangan dan praktik bisnis

D. Kriteria Keberhasilan

Technopreneur yang Lulus dari Proses Inkubasi

Kriteria keberhasilan training technopreneurship ini antara lain :

1. Menghasilkan calon technopreneur yang berasal dari mahasiswa

2. Jiwa, sikap, pengetahuan dan ketrampilan di bidang kewirausahaan meningkat.

3. Calon technopreneur menguasai tentang materi kewirausahaan 
4. Calon technopreneur menguasai ketrampilan pembuatan batako

5. Menghasilkan wirausaha baru yang mampu menciptakan lapangan kerja

Dan juga beberapa kelemahan pengajaran mata kuliah yang mempengaruhi kemampuan

mahasiswa.

Beberapa kelemahan tersebut antara lain:

1. Materi yang disampaikan hanya menjadi pengetahuan, tidak menjadi praktek (aplikasi).

2. Studi kasus yang dipelajari di kelas berdasarkan data sekunder (artikel) sehingga tidak analisis tidak aktual dan dialogis.

3. Ketiadaan obyek usaha yang spesifik sehingga informasi tentang bisnis tertentu tidak komprehensif.

4. Informasi yang didapatkan untuk menyusun rencana, proposal dan evaluasi bisnis tidak valid dan riil serupa dengan kondisi lapangan

5. Tidak tersedia laboratorium produksi yang memadai sehingga mahasiswa memiliki gambaran menjalankan bisnis sejak produksi, pemasaran dan keuangan yang harus dikelola.

Oleh karena itu dengan adanya kegiatan enterpreneur diharapkan bisa menjadi inkubator yang lengkap bagi para peserta training, tidak hanya berupa teori dalam kelas namun juga secara langsung dipraktekkan di lapangan.

\section{E. Keberlanjutan Pembinaan}

\section{Technopreneur}

Peserta setelah lulus dari proses pelatihan ini maka akan tercatat sebagai alumni dan masih berhak memiliki akses di kandang ini. Mereka akan diberikan wadah organisasi yang bisa digunakan untuk saling komunikasi dan tukar pendapat, sehingga para peserta yang akan terjun ke dunia technopreneur akan memiliki komunitas yang mendukung. Mereka akan diberikan akses seluas-luasnya untuk konsultasi dan mempelajari kembali apa yang sudah diberikan selama proses pelatihan berlangsung. Para peserta 
yang sudah terjun ke dunia technopreneur, diharapkan melaporkan ke wadah organisasi alumni sehingga bisa sharing pengalaman pada anggota lainnya.

\section{HASIL DAN PEMBAHASAN}

Entrepreneur Pembuatan batako merupakan program utama dari pelaksanaan program pengembangan intrepreneur kampus di workshop Pendidikan Bangunan Universitas Sebelas Maret Surakarta tahun 2016. Mahasiswa yang telah terdaftar dan terseleksi selanjutnya mendapatkan pembekalan singkat dari Dosen Pembimbing Lapangan dan beberapa training pengembangan usaha baik dalam kampus maupun di luar kampus. Pembuatan usaha kampus memilih pembuatan batako dan paving blok salah satunya karena latar belakang program studi, disamping itu kebutuhan dilapangan akan keduanya juga sangat banyak. Dan pelaksanaan pembuatan batako sesuai dengan pembekalan.

$$
\text { Proses produksi batako }
$$
menggunakan bahan dari pasir dan semen dicampur dengan sedikit air.
Perbandingan campuran antara semen dan pasir digunakan 1 bagian semen dengan 7 bagian pasir. Pasir berasal dari Kali Woro Merapi dan semen yang digunakan jenis semen I yang dijual di toko bangunan. Sebelum dilakukan pencampuran bahan dan alat pencetak disiapkan. Penyiapan bahan antara pasir dan semen dibuat perbandingan dengan menggunakan takaran ember. Kemudian ditakar semua bahan-bahan tadi baru dilakukan pencampuran dengan menggunakan cangkul diadukaduk sampai rata bahannya. Setelah rata baru dikasih air sedikit demi sedikit untuk membasahi bahan campuran. Proses selanjutnya pencetakan menjadi batako dengan memasukan bahan kedalam cetakan dan dilakukan pemadatan, kemudian cetakan dilepas.

Adapun Tujuan dari program entrepreneur kampus ini adalah untuk melatih mahasiswa belajar berwirausaha, memanagemen sebuah perusahaan dan menghasilkan lapangan pekerjaan. Dari tujuan tersebut program yang kami jalankan ini masih belum dapat mencapai semua tujuan 
itu, hal tersebut dikarenakan program Entrepreneur kampus ini merupakan program yang baru dirintis.

Pelaksanaan entrepreneur kampus mendapat beberapa masalah. Masalah yang ada merupakan salah satu factor yang mempengaruhi keberjalanan pelaksanaan produksi batako.

Permasalahan yang pertama dari pelaksanaan produksi batako ini adalah keterampilan SDM, campuran bahan yang belum menemukan formula, dan factor logistic. Keterampilan mahasiswa yang masih belum begitu baik karena masih dalam taraf belajar, hasil batakonya pun tidak sesuai dengan yang ada di pasaran. Pembuatan dengan alat manual (pemadatan dengan tangan) yang belum begitu terampil sering kali hasil batako kurang padat dan banyak yang retak, sehigga produksinya harus diulangi. Tak hanya keterampilan saja akan tetapi tenaga juga, tenaga manusia akan semakin berkurang ketika digunakan terus menerus. Pemadatan yang menggunakan manual hasilnya juga semakin lama semakin kurang bagus. Kedua adalah factor campuran antara semen, pasir dan air. Untuk semen kami sudah dapatkan dari tempat training produksi batako, namun untuk air tidak bisa dipukul rata. Air sangat berpengaruh pada hasil cetakan batako dan paving blok. Kebanyakan air pada campuran akan membuat batako dan susah untuk lepas dari cetakan, sebaliknya jika kekurangan air maka hasil cetakan batako akan mudah retak dan tidak jadi. Hingga akhirnya untuk air ini kami temukan takaran yang sesuai dengan perbandingan 1 semen : 7 pasir : 1 air. Ketiga adalah factor logistic atau bahan, dari kualitas pasir, semen dan air. Pasir yang ada memiliki kualitas sedang sehingga hasil dari batako juga tidak terlalu bagus, jika menginginkan hasil yang bagus maka pasir terlebih dahulu harus di ayak dan dicuci. Hal tersebut dapat menjadikan pasir bersih dari lumpur dan zat organic lainnya.

Entrepreneur kampus ini merupakan program kerja yang baru dirintis sehingga untuk pengembangan pelaksanaan program kerja kami masih fokuskan pada proses produksi. Penemuan campuran dan teknik yang 
benar akan menghasilkan batako dan paving blok yang berkualitas. Ketika pelaksanaan produksi ini berhasil untuk selanjutnya akan dikembangkan lebih lanjut hingga nanti akan berjalan entrepreneur kampus yang bisa menyerap tenaga kerja dari mahasiswa atau masyarakat sekitar, dan juga sebagai sarana untuk melatih jiwa jiwa entrepreneur mahasiswa.

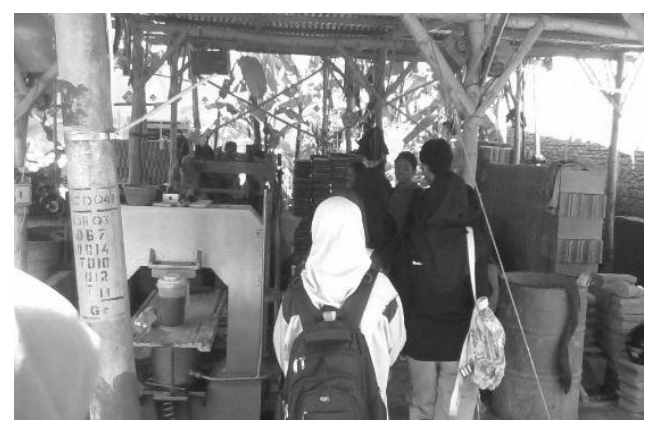

Gambar 1. Magang ditemapat industri batako

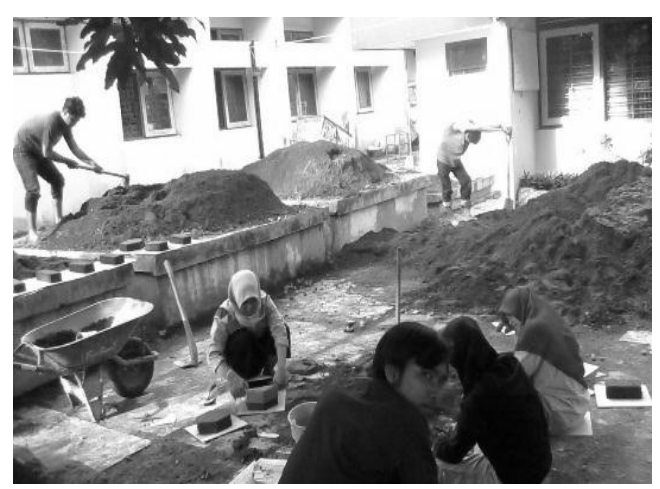

Gambar 2. Proses produksi batako dikampus
Dalam satu hari produksi batako sekitar 25 buah perhari yang dilakukan secara bergantian antar mahasiswa. Pembuatan batako yang bertempat dikampus biasa kami mulai pada pukul 08.30 wib sampai pukul 15.00 WIB. Hasil kegiatan kewirausahaan kampus telah terbentuk unit usaha batako dan kantor pengelolaan yang berada di kampus Pabelan UNS. Pada kegiatan ini melibatkan 10 mahasiswa dari berbagai program studi yang paling banyak dari program studi PTB. Batako yang dihasilkan 2 jenis antara lain batako pejal dan batako berlubang. Produk yang dihasilkan berjumlah 600 buah dengan ukuran $10 \mathrm{~cm} \times 15 \mathrm{~cm} \times 30 \mathrm{~cm}$ dan $10 \mathrm{~cm} \times 20 \mathrm{~cm} \times 40 \mathrm{~cm}$. Ukuran ini yang biasa dipakai untuk membuat dinding pada rumah maupun bangunan sehingga untuk sesuai dengan kebutuhan dari masyarakat. Pada saat ini batako yang dihasilkan telah digunakan untuk praktek mahasiswa pada mata kuliah Ilmu Bahan Bangunan pada program studi PTB. 


\section{KESIMPULAN}

1. Peran serta kampus sangat baik dalam mendukung progran kewirausahaan kampus dengan menyediakan ruangan untuk kantor operasional dari program ini.

2. Keberlangsungan

kegiatan kewirausahaan kampus dikendalikan sepenuhnya oleh mahasiswa dalam mengendalikan usahanya, dan dibantu oleh dosen sebagai pembimbing.

3. Melalui pelaksanaan program ini dapat meningkatkan kepedulian dan empati mahasiswa pada permasalahan yang ada pada mahasiswa sehingga terjadi perubahan perilaku mahasiswa, menumbuhkan jiwa kepemimpinan, kewirausahaan, dan peningkatan kemampuan pemecahan masalah berbasis masyarakat

4. Melalui pelaksanaan program kegiatan ini dapat mengatasi sebagian permasalahan dimasyarakat melalui metode pemberdayaan dalam bidang sarana dan prasarana didalam masyarakat.

5. Menerapkan ilmu yang didapatkan dimeja kuliah untuk dikembangkan di masyarakat khususnya dalam pembuatan batako yang merupakan salah satu bahan bangunan.

\section{DAFTAR PUSTAKA}

BPPT, 2010a. Kajian Pengembangan PendidikanTechnopreuneurship.

Pusat Pengkajian Kebijakan Peningkatan Daya Saing, Jakarta. BPPT, 2010b. "Naskah Akademis Kebijakan Pengembangan Technopreneurship." Mimeo, Pusat Pengkajian Kebijakan Peningkatan Daya, Jakarta.

Gerald, G., Meredith, Kewirausahaan; Teori dan Praktek, Jakarta:PPM, 1996 (terjemahan)

Johnston, Neil A. 1993. Pembuatan Batako . Ambon: Universitas Patimura

Nasution, Arman Hakim, Bustanul Arifin Noer dan Mokh. Suef, 2007. 
Enterpreneurship. Membangun

Spirit Technopreneurship,

Penerbit Andi, Yogyakarta.

Nugroho, Suharyadi dkk. 2007

Kewirausahaan Membangun

Usaha Sukses Sejak Usia Muda.

Jakarta : Salemba Empat

http://news.ipb.ac.id , Diposting oleh admin pada tanggal 30 August 2010 , Limbah Slag Baja Termasuk dalam Limbah B3, diakses tanggal 1 November 2012.

http://ekonomiteknik-

itt.blogspot.com/2012/01/benefi

t-cost-ratio.html, diakses tanggal

4 Februari 2017

http://eprints.undip.ac.id/33843/6/179

4_CHAPTER_II.pdf, diakses

tanggal 21 Maret 2017

http://www.pondokburuhkonstruksi.co

$\mathrm{m} /$ paving.html, diakses tanggal

21 Maret 2017

http://membangun-

rumah8870.blogspot.com/2012/

09/paving-block.html , diakses tanggal 21 Maret 2017

http://www.pavingbloc.com/paving-

block-adalah/, diakses tanggal 21

Maret 2017

http://pavingblockindonesia.com/pavin

g-block.html, diakses tanggal 21

Maret 2017 


\section{BIODATA PENULIS}

\section{Ida Nugroho, S.T., M.Eng.}

Tenaga pendidik atau dosen program studi S1 Pendidikan Teknik Bangunan Fakultas Keguruan dan IImu Pendidikan Universitas Sebelas Maret. Lulusan S2 Teknik Sipil Struktur Universitas Gadjah Mada pada tahun 2008. Saat ini mengampu beberapa mata kuliah yakni Teknologi Beton, Struktur Beton III, Statistika, Teknik Penyehatan, Praktek Beton, Praktek Ukur Tanah I dan II, Praktek Plambing dan Utilitas, Teknik Gempa, Microtheaching dan Praktek Kayu I dan II 